\title{
EUROPEANISATION OF THE MACEDONIAN PRIVATE INTERNATIONAL LAW - LEGAL EVOLUTION OF A NATIONAL PRIVATE INTERNATIONAL LAW ACT
}

\author{
Ilija Rumenov, PhD, Assistant Professor \\ University Ss Cyril and Methodius - Skopje, \\ Faculty of Law "Iustinianus Primus" \\ Bul. Goce Delcev 9, 1000 Skopje, N. Macedonia \\ i.rumenov@pf.ukim.edu.mk
}

\begin{abstract}
The new Private International Law Act of the Republic of North Macedonia (hereinafter the PIL Act 2020) has been adopted in 2020. It represents one of the most comprehensive codification of European Union private international law (hereinafter the EU PIL) provisions in national private international law act. The PIL act 2020 implements most of the EU conflict of law rules and EU jurisdictional criteria especially those that have universal application. The most significant characteristics of PILA 2020 are: firstly, the act has limited the exclusive jurisdictional criteria; secondly, it introduced habitual residence as one of the main jurisdictional and conflict of law criteria; and thirdly, the act 'mirrors' the provisions that are present in the EU regulations. Moreover the PILA 2020 has positioned direct link between the decisions of the Court of Justice of the European Union regarding the EU PIL Regulations and the national courts, although N. Macedonia is still a candidate country to the EU. This Europeanisation of the Macedonian PIL has been done for two reasons: first, to modernize the rules in line with the new PIL trends, and secondly to prepare the Macedonian judges for the forthcoming radical change in the PIL when N. Macedonia becomes a full member in the EU. The intention of this article is not to give full detailed analyses of every provision in the new PILA 2020 but rather to provide for general overview of the solutions present in this act, as well to determine the main principles and new tendencies that would define the Macedonian private international law in future.
\end{abstract}

Keywords: Private International Law; Private International Law Act of the Republic of North Macedonia; Conflict of Laws; International Jurisdiction; Recognition and Enforcement of Foreign Judicial Decisions 


\section{THE DEVELOPMENT OF PRIVATE INTERNATIONAL LAW IN N. MACEDONIA IN THE PERIOD 1982-2020}

The new Private International Law Act (hereinafter the PILA 2020) ${ }^{1}$ of N. Macedonia has been adopted in January 2020 and represents second systematization of private international law rules since its independence from Socialist Federative Republic of Yugoslavia (hereinafter the SFRY) in 1991. However, to properly understand the "DNA" of the new PILA 2020 notion has to be given to its predecessors: the Private International Law Act of 2007 (hereinafter the PILA 2007) ${ }^{2}$ and Act Concerning the Resolution of Conflicts of Laws with Provisions of Other States in Certain Matters (hereinafter the PILA 1982). ${ }^{3}$ Also, the duty imposed by Article 68 of the Stabilization and Association Agreement with the European Communities and their Member States $(\mathrm{SAA})^{4}$ for adaptation of the internal laws and compatibility of the legal sources of $\mathrm{N}$. Macedonia with the EU legal sources has significant influence on the structure and the substance of the new PILA 2020.

The PILA 2007 in its structure, had many similarities with the PILA 1982 which was the first systemized PIL act a law enacted on a federal level in the SFRY. ${ }^{5}$ In essence, the PILA 1982 represented the first codification of private international law rules in SFRY. Before that law came into force, private international law legal issues in SFRY were either scattered among different acts or they were not regulated. ${ }^{6}$ For example, recognition of foreign judicial decisions before the enactment of the PILA 1982 was provided according to the Law on Civil Procedure ${ }^{7}$ while

1 Private International Law Act (Закон за меѓународно приватно право), Official Gazette, no. $32 / 2020$

2 Private International Law Act (Закон за меѓународно приватно право), Official Gazette, no. 87/2007 and 156/2010

3 Act Concerning the Resolution of Conflicts of Laws with Provisions of Other States in Certain Matters (Закон за решавање на судирот на законите со прописите на другите држави во одредени односи), Official Gazette of the SFRY, no.43/1982

4 Stabilisation and Association Agreement between the European Communities and their Member States, of the one part, and the former Yugoslav Republic of Macedonia, of the other part, Official Gazette of Republic of Macedonia, no. 28/2001

5 For more comprehensive understanding of the historical development of the act see Dika M.; Knežević G.; Stojanović S., Komentar zakona o medunarodnom privatnom i procesnom pravu, Nomos, (1991); Џунов Т. Меѓународно приватно право, Скопје, (1995), 227-235

6 Varadi T. et al., Mecunaodno privatno pravo, deseto izdanje, JP “Službeni Glasnik', Beograd, 2008, p. 61

7 Articles 16 to 22 of the Law on civil procedure, Official Gazette of the FPRY, no.4/57 
the enforcement of foreign judicial decisions was left to the Law on Enforcement procedure. ${ }^{8}$ All of these legal issues and the legal vacuum that existed over some issues in SFRY were settled with the codification and coming into force of the PILA 1982. ${ }^{9}$

The similarity between the PILA 2007 and the PILA 1982 was evident. Both laws were systematically divided into six chapters containing rules for international jurisdiction (and procedure), conflict of law rules, recognition and enforcement rules and other rules were also contained within them. These two acts were not only similar in their structure, but also the similarity could be seen in the substance of the rules present in these acts. ${ }^{10}$ This provided for consistent understanding of the rules and the use of practical and doctrinal materials in the interpretation of the solutions in both PIL acts.

\section{THE STRUCTURE AND THE SOLUTIONS IMPLEMENTED IN THE NEW PILA 2020}

\subsection{Structure of the new PILA 2020}

The first impression of the structure of the new PILA 2020 is that it has been modestly altered from its predecessor the PILA 2007. The PILA 2020 has been constructed to be more "user friendly" identifying and providing for more sections and subsections making it easier for the judiciary and the legal practitioners to implement this act. Similarly to its predecessor, the PILA 2020 is composed of six components ${ }^{11}$ covering the following issues: basic provisions (part one); applicable law (part two); international jurisdiction and procedure (part three); recognition and enforcement of foreign judicial decisions (part four); special provisions (part five) and final and transitory provisions (part six). Inside these parts in the PILA 2020, the influence of the PILA 2007 and PILA 1982 is easily traceable, providing for the same systematization of the main PIL issues.

The first change in the new PILA 2020 can be seen in part two (applicable law) providing for two chapters instead of only one, as it was provided in the PILA 2007. In the PILA 2020 the first chapter of part two is called "General part" (articles 7-14) and refers to different PIL issues which apply to all of the conflict

8 Law on Enforcement procedure, Official Gazette of the SFRY, no.20/78

9 Živković M.; Stanivuković M, Međunarodno privatno pravo (opšti deo), Beograd, Službeni glasnik, 2006, p. 41-42

10 For more on the novelties introduced with the PILA 2007 see, Deskoski T., The new Macedonian Private International Law Act of 2007, Yearbook of Private International Law, vol. X, 2008, p. 441-459

11 In the PILA 2020 these components are called parts while in the PILA 2007 they are given as chapters 
of law rules (renvoi, states with non-unified legal system, determination of the content of the foreign law, overriding mandatory provisions, general exemption clause, interpretation and application of foreign law, public policy and characterization). Moreover, the second chapter of part two is systematically different from the systematization of the special part in PILA 2007. In the PILA 2007 all of the rules regarding the determination of the applicable law were given altogether (articles 15-51), containing only titles in front of every article. The principle of the PILA 2020 to make the act more "user friendly", provides for systematization of the legal issues in sections and subsections divided according to the subject matter and with titles in front of every component and then containing titles which identify the subject matter for every article.

This systematization is followed in part three of the PILA 2020, which contains two chapters: chapter one that refers to international jurisdiction containing general section regarding international jurisdiction, special section for choice of court agreements, and special jurisdictional rules in different subject matters given in subsections (personal status, family relations, succession, rights in rem, contractual and non-contractual relations). Chapter two of part three refers to other rules relating to the procedure (applicable law regarding the procedure; capacity to be a party in a lawsuit and capacity to conduct legal proceedings; and cautio iudicatum solvi).

Part four of the PILA 2020 contains three chapters: chapter one (definitions), chapter two (conditions) containing two sections (section one - conditions determined ex officio and section two - conditions determined upon objection by the parties) and chapter three procedure for recognition of foreign judicial decisions. The fifth part is generally the same as the counterpart in PILA 2007.

\subsection{The new solutions implemented in the PILA 2020}

The main differences between the new PILA 2020 and its predecessor the PILA 2007 are the solutions provided in the act. These new solutions are constructed around the ideas to enhance transparency of the provisions, to adopt an open and to international approach in dealing the PIL issues and in that process to make the rules more easily accessible to legal practitioners. ${ }^{12}$ To achieve these ideas, the PILA 2020 has set three main goals.

The first goal of the new PILA 2020 is to make the act more "user friendly", containing sections and subsections divided according to the subject matter and with titles in front of every component and then containing titles which identify the

12 Kramer X. et al., Study by the European Parliament's Committee on Legal Affairs "A European framework for private international law: current gaps and future perspectives", PE 462.487, 8 
subject matter for every article. Such structure of the PILA 2020 should make the act more easily accessible to legal practitioners and in that process it should enhance the transparency of the provisions.

Secondly, the PILA 2020 tends to implement most of the new tendencies of the EU PIL rules and those of the Hague Conference of Private International Law regarding the determination of the applicable law, jurisdictional criteria and the rules regarding recognition and enforcement of foreign decisions. To achieve this goal "Europeanisation of the PIL"13 the PILA 2020 is transposing the private international law rules of the EU, especially those which have 'universal application'. ${ }^{14}$

13 European Private International Law is consisted of approximately twenty instruments. For more on the development and future prospects of EU PIL see, Kramer, X., A Common Discourse in European Private International Law? A View from the Court System, in: von Hein J.; Kieninger E.M.; Rühl G., (eds.), How European Is European Private International Law, Intersentia, 2018/19, [https://ssrn.com/ abstract=3207771], accessed 04. July 2020, p. 4-5; Kramer X., et al., A European framework for private international law: current gaps and future perspectives. Study, European Parliament, 2012; Kramer X., Current gaps and future perspectives in European private international law: towards a code on private international law? Briefing note, European Parliament 2012; Kramer X., 'European Private International Law: The Way Forward. Indepth analysis' in Workshop on Upcoming Issues of EU Law, European Parliament, Brussels 2014, pp. 77-105; Von Hein; Rühl G., 'Towards a European code on private international law? Study', in Cross-border activities in the EU: Making life easier for citizens, Workshop for the JURI Committee, European Parliament, 2015, pp. 8-53. The process of the "Europeanisation of the PIL" refers to the adoption of the PIL rules that are being formed at European level instead of traditionally at national level. For more on this process and the relationship with globalization see, Van Den Eeckhout V., The Instrumentalisation of Private International Law: Quo Vadis? Rethinking the 'Neutrality' of Private International Law in an Era of Globalisation and Europeanisation of Private International Law, August 22, 2013, [https://ssrn.com/abstract=2338375], accessed 04. July 2020, pp. 3-4

14 There are several provisions in the EU Regulations that tend to harmonize the conflict of law rules within the EU providing for 'universal application' of these provisions such as Article 2 of the Regulation (EC) No 593/2008 of the European Parliament and of the Council of 17 June 2008 on the law applicable to contractual obligations (Rome I) OJ L 177, 4.7.2008, 6-16; Article 3 of the Regulation (EC) No 864/2007 of the European Parliament and of the Council of 11 July 2007 on the law applicable to non-contractual obligations (Rome II), OJ L 199, 31.7.2007, 40-49.; Article 4 of the Council Regulation (EU) No 1259/2010 of 20 December 2010 implementing enhanced cooperation in the area of the law applicable to divorce and legal separation OJ L 343, 29.12.2010, 10-16; Article 20 of the Regulation (EU) No 650/2012 of the European Parliament and of the Council of 4 July 2012 on jurisdiction, applicable law, recognition and enforcement of decisions and acceptance and enforcement of authentic instruments in matters of succession and on the creation of a European Certificate of Succession OJ L 201, 27.7.2012, 107-134; and Article 20 Council Regulation (EU) 2016/1103 of 24 June 2016 implementing enhanced cooperation in the area of jurisdiction, applicable law and the recognition and enforcement of decisions in matters of matrimonial property regimes OJ L 183, 8.7.2016, 1-29. For more on the 'universal application' of these rules see, Deskoski T.; Dokovski V., Lex Contractus for Specific Contracts under Rome I Regulation, Iustinianus Primus Law Review, vol. 10, 2019, p. 3; Behr V., Rome I Regulation a-Mostly_Unified Private International Law of Contractual Relationships within - Most —of the European Union, Journal of Law and Commerce, vol. 29, no. 2, 2019, p. 238; Kramer X., The Rome II Regulation on the Law Applicable to Non-Contractual Obligations: The European private international law tradition continued, Nederlands Internationaal Privaatrecht (NIPR) 
These rules are constructed according to the firmly rooted principle in the private international law instruments of the EU and the Hague Conference on Private International Law, by which the law designated by the Regulation shall apply whether or not it is the law of a participating Member State and that intra-Union and extra- Union situations are dealt with on an equal basis. ${ }^{15}$ Moreover, the legislator bears in mind that EU PIL is still in construction, ${ }^{16}$ consisted not only of the legal instruments of the European Council and the European Parliament, but also of international conventions (especially significant are those of the Hague Conference of Private International Law). ${ }^{17}$ Furthermore, in the EU there are certain tendencies and debates whether as a long term option a more coherent approach for the EU PIL is necessary trough adoption European Code on Private International Law which will cover the general rules of PIL (Regulation Rome ' 0 '). ${ }^{18}$ On the other hand, there are certain discrepancies in the implementation of the EU PIL rules that can be traced in many of the Member States of the EU. ${ }^{19}$ Therefore, to properly implement the EU PIL rules and in the same time to provide for more coherent approach regarding the EU PIL, the national legislator opted to incorporate many of these PIL tendencies (increased use of party autonomy as a connecting factor, reduction of nationality as a connecting factor, introduction of habitual residence as an alternative to the domicile as a connecting factor/jurisdictional criteria, limitation of the exclusive jurisdictional grounds etc.) in the PILA 2020 so the judges and the practitioners would get acquainted with the EU PIL rules even before N. Macedonia becomes Member State to the EU.

Lastly, the intention of the legislator was to conduct Europeanisation of the national PIL but with specific notion that national private international law act does not only apply among Member States of the EU, but also it applies in regard third countries. So this notion of universality of the provisions in the PILA 2020 played important role in the drafting of the rules, based on the experiences from the Hague Convention on Jurisdiction, Applicable Law, Recognition, Enforcement

2008, no. 4, p. 415; Ahern B.; Binchy W. (ed.), The Rome II Regulation on the Law Applicable to Non-Contractual Obligation - A New International Litigation Regime, Martinus Nijhoff Publishers, Leiden Boston, 2009, p. 265; Boele Woelki K., For better or for worse: The Europeanisation of International Divorce Law, Yearbook of Private International Law, vol. 12, 2010, p. 29

15 Boele Woelki, ibid., p. 29

16 Ibid., p. 20

17 Ibid.

18 Von Hein; Rühl, op. cit., note 13, p. 26-46; Kramer, X., op. cit., note 13, p. 20; Kramer et al., op. cit., note 13, pp. 89-92

19 Hess, B.; Law, S.; Ortolani P. (eds.), An evaluation study of national procedural laws and practices in terms of their impact on the free circulation of judgments and on the equivalence and effectiveness of the procedural protection of consumers under EU consumer law, JUST/2014/RCON/PR/CIVI/0082, 2017, p. 45 
and Co-operation in Respect of Parental Responsibility and Measures for the Protection of Children (hereinafter the 1996 Hague Convention); Hague Convention on the International Recovery of Child Support and Other Forms of Family Maintenance (hereinafter the 2007 Hague Convention); Hague Protocol on the Law Applicable to Maintenance Obligations (hereinafter the 2007 Hague Protocol) and the Hague Convention on Choice of Court Agreements (hereinafter the 2005 Hague Convention).

\subsubsection{New solutions regarding the basic provisions}

The basic provisions of the PILA 2020 have been structurally changed in comparison with the PILA 2007. This part now only contains six articles (PILA 2007 contained 14 articles). The first major difference of PILA 2020 from its predecessor is that it introduces the formation of the new Chapter I in the second part, where the general rules which refer to the determination of the applicable law are now transferred from the basic provisions of Part I.

The scope of the PILA 2020 has been slightly changed and in comparison with the PILA 2007 now only contains one paragraph covering all of the PIL issues (applicable law, international jurisdiction and procedure and recognition and enforcement). Also, this rule does not go in specific subject matter of the relations covered by the PILA 2020, ${ }^{20}$ but contains general definition that the PILA 2020 applies to "... private legal relations having an international element...". ${ }^{21}$

There is slight difference in Article 2 of the PILA 2020 which now provides for title "Supremacy of international agreements". In respect of the provisions contained in this article it provides for certain clarification that the provisions are not applicable if they are regulated with ratified international treaties.

Article 3 of the PILA 2020 refers to rules regarding filling of legal gaps and contains simplification of the bases upon which the relevant authority can fill the legal gaps. The PILA 2007 contained several bases upon which the relevant authority can fill the legal gaps: the provisions and principles of the private international law act, the principles of the system of law of the Republic of N. Macedonia and lastly the principles of private international law. ${ }^{22}$ The new rule provided in Article 3 of

\footnotetext{
20 This was case with the PILA 2007 which in Article 1 provided “...personal (status), family, labour, property and other civil relationship having an international element.” Identical solution was contained in Article 1 of PILA 1982

21 Article 1 of the PILA 2020

22 Article 4 of the PILA 2007
} 
PILA 2020 provides only for two bases: the provisions of the private international law act and the principles of private international law.

The rules in the PILA 2007 regarding multiple citizenship, ${ }^{23}$ stateless persons ${ }^{24}$ and habitual residence ${ }^{25}$ are significantly changed in the PILA 2020. The new rule in PILA 2020 regarding multiple citizenship has introduced the habitual residence as an alternative of the domicile, so if a person possesses two or more foreign citizenships and none of them is Macedonian, then that person will be regarded as having citizenship of the State where "...he/she has its habitual residence". ${ }^{26}$ The other solutions in the PILA 2020 regarding multiple citizenship (closest connection and one of the citizenships is a Macedonian) have remained the same as the solutions in PILA 2007. Moreover, in the PILA 2020 the rules regarding stateless persons are broadened, adding another category- refugees. ${ }^{27}$ So if the person is a stateless persons or a refugee then the applicable law instead of citizenship as a connecting factor, will be determined according to their habitual residence or ordinary residence. ${ }^{28}$

Lastly, the mere definition of habitual residence for natural person is changed from the definition given in PILA 2007, in aspect that it has left out the limitation of six months for creation on habitual residence and giving more flexibility in determination of the habitual residence. ${ }^{29}$ Such solution is welcomed, since the understanding of whether a person has acquired a habitual residence or not is left to the relevant authority to determine based on the factual situation. ${ }^{30}$ For natural persons acting in the course of business and for companies and other legal persons there are specific rules provided in Article 75 and 87 of the PILA 2020, modeled according to definitions of habitual residence provided in Article 19 of the Rome I Regulation and Article 23 of the Rome II Regulation.

\footnotetext{
$23 \quad$ Article 11 of the PILA 2007

24 Article 12 of the PILA 2007

25 Article $12 \mathrm{a}$ of the PILA 2007

26 Article 4 of the PILA 2020.

27 Article 5 of the PILA 2020.

28 Article 5 of the PILA 2020.

29 Article 6 of the PILA 2020.

30 For more on the determination of habitual residence according to the Brussels IIbis Reguation and the 1980 Child Abduction Convention see, Rumenov I., Determination of the Child's Habitual Residence According to the Brussels II bis Regulation, Pravni Letopis, Inštitut za primerjalno pravo pri Pravni fakulteti v Ljubljani, Ljubljana Slovenia, 2013 pp. 57-81; Rumenov I., The legal paradox of child's habitual residence: How to uniformly understand a factual concept?, Iustinianus Primus Law Review, vol. V, no. 8, 2014, pp. 1-15
} 


\subsubsection{New solutions regarding the applicable law}

\subsubsection{General provisions}

The rules regarding the determination of the applicable law are structured in Part II of the PILA 2020. Significant novelty in the PILA 2020 from its predecessor is that it introduces the formation of the new Chapter I in the second part. Such structural change was done to provide for more focused application of the general rules regarding the determination of the applicable law. The rules provided in this chapter refer to renvoi, ${ }^{31}$ non-unified legal system, ${ }^{32}$ determination of the contents of the foreign law, ${ }^{33}$ interpretation and application of foreign law, ${ }^{34}$ general exemption clause, ${ }^{35}$ public policy, ${ }^{36}$ overriding mandatory provisions ${ }^{37}$ and a special rule regarding characterization. ${ }^{38}$

The main principles contained in the provision regarding renvoi in PILA 2007, are also present in Article 7 of the PILA 2020 providing for single renvoi system and containing exclusions in cases when the parties have the right to choose the applicable law. The legislator opted to enumerate the legal relationships where the PILA allows the parties to choose the applicable law, making it much more "user friendly" ${ }^{39}$ Another aspect introduced in the PILA 2020 regarding renvoi is that it applies the single renvoi system not only when the applicable law refers back to the Macedonian law, but also to third states, thus resolving one ambiguity that was present in PILA 2007 and its predecessors. ${ }^{40}$

The rules regarding the determination of the contents of the foreign law have in general remained the same as the ones in the PILA 2007 (ex officio determination, with significant role of the ministry of justice and possibility of procurement of public documents of the contents of the foreign law). The new aspect introduced in Article 9 of the PILA 2020 is that the parties now can provide an expert opinion for the content of the foreign law, however the court is not bound by its findings.

\footnotetext{
$31 \quad$ Article 7 of the PILA 2020

32 Article 8 of the PILA 2020

33 Article 9 of the PILA 2020

34 Article 10 of the PILA 2020

35 Article 11 of the PILA 2020

36 Article 12 of the PILA 2020

37 Article 13 of the PILA 2020

38 Article 14 of the PILA 2020

39 For more on renvoi in Macedonian law, see Гавроска П., Дескоски Т., Меѓународно приватно право, Скопје,, 2011, pp. 248-256

40 Regarding the problems which arise out of the implementation of renvoi in relation to third states see Dika; Knežević; Stojanović op. cit., note 5, pp. 26-30
} 
Article 10 of the PILA 2020 refers to interpretation and application of foreign law. This rule must be seen together with Article 14 which refers to the characterization. The PILA 2007 and its predecessors regarding characterization covered only the scenario for the application of foreign law, meaning that the law of the foreign State is applied in accordance with its meaning and the notions that it contains (lex causea characterization). ${ }^{41}$ This was done intentionally, because according to the understanding of the previous legal doctrine, implicitly it was understood that the Court in first step, applied the lex fori characterization when it applied the domestic conflict of law rules and reached the foreign law as applicable. ${ }^{42}$ The PILA 2020 provides for two step characterization, providing explicitly in Article 14 of the PILA 2020 for first step lex fori characterization. Then the second step of characterization provides for lex causae characterization, meaning that if the foreign law is applicable, then the law of the foreign State is interpreted and applied in accordance with its meaning and the notions that it contains. ${ }^{43}$ Seen together with Article 9 of the PILA 2020 the consequence of non-application of foreign law or incorrect application of foreign law is base for legal remedy. ${ }^{44}$

The new PILA 2020 contains a rule regarding legal institutes unknown in the domestic legal system, providing that this legal institutes should be interpreted according to the Macedonian legal system, but when with such acts the proper position of this legal system cannot be determined then then the legal system from which this legal institute originates, will be taken into consideration for the characterization..$^{45}$

The rules regarding the general exemption clause in comparison to the PILA 2007 have been more precisely drafted. Namely, the rules given in Article 3 of PILA 2007 contained only partial solution that in the situations when if it was evident that the legal relationship didn't have significant connection with the applicable law, then the Courts would not apply that law. Article 11 of the PILA 2020 goes further and provides that the Courts would apply the law which has closer connection with the legal relationship. ${ }^{46}$

Regarding the overriding mandatory provisions in the PILA 2020, they have been substantially changed from the provisions in the PILA $2007^{47}$ and modeled ac-

\footnotetext{
41 For more on this rule see, ibid., pp. 35-42; Varadi et al., op. cit., note 5, pp. 128-129

42 Dika; Knežević; Stojanović op. cit., note 5, pp. 35-42

43 Article 10 of the PILA 2020

44 Article 10 (2) of the PILA 2020

45 Article 14(2) of the PILA 2020

46 Article 11(2) of the PILA 2020

47 For more on the solutions regarding the mandatory rules provided in the PILA 2007 see Deskoski T., The new Macedonian Private International Law Act of 2007, pp. 445-446
} 
cording to Article 9 of the Rome I Regulation ${ }^{48}$ providing for application of rules in the law of Republic of North Macedonia which are regarded as crucial for safeguarding its public interests, such as its political, social or economic organization, to such an extent that they are applicable to any situation falling within their scope, irrespective of the law otherwise applicable. ${ }^{49}$ As an exemption, the Court would consider the overriding mandatory provisions of another country, which has close connection with the legal relationship and in considering whether to give effect to those provisions, regard shall be had to their nature and purpose and to the consequences of their application or non-application. ${ }^{50}$

The public policy rule in the PILA 2020 got slight modification, in context of the 'Europeanisation of the PIL'51 providing for higher threshold for its application, given that the consequences of the application of the applicable law would be 'manifestly' contrary to the public policy in Republic of North Macedonia. ${ }^{52}$

\subsubsection{Specific provisions}

\section{Legal status of natural and legal persons}

The first specific provisions in the PILA 2020 refers to legal capacity and capacity to contract of natural person and legal person. In comparison with the rules in the PILA 2007 the new rules are structurally different. They are much more "user friendly" divided in two subsections: one referring to natural persons ${ }^{53}$ and one

48 For more on the importance of Article 9 of the Rome I Regulation see, Crawford E.B.; Carruthers J.M, Connection and Coherence Between and Amoung European Instruments in the Private International Law of Obligations, International and Comparative Law Quarterly, vol. 63, 2014, pp. 1-29; Pauknerová, M. Mandatory rules and public policy in international contract law. ERA Forum 11, 2010, pp. 29-43; Hellner M., Third Country Overriding Mandatory Rules in the Rome I Regulation: Old Wine in New Bottles?, Journal of Private International Law, 2009, pp. 447-470

49 Article 13 (1) of the PILA 2020

50 Article 13(2) of the PILA 2020

51 De Lange R., The European Public Order, Constitutional Principles and Fundamental Rights, Erasmus Law review, 2007, pp. 3-24; Hess B.; Pfeiffer T., Interpretation of the Public Policy Exception as referred to in EU Instruments of Private International and Procedural Law', European Parliament 2011, [www. europarl.europa.eu/studies], accessed 20. June 2020; Hoško T., Public Policy as an Exception to Free Movement within the Internal Market and the European Judicial Area: A Comparison, Croatian Yearbook of European Law and Policy, vol. 10, 2014, pp. 201-202; Kessedijan C., Public Order in European Law, Erasmus Law Review, vol. 1, issue 1, 2007, pp. 25-36.

52 Article 12 of the PILA 2020. For more on the interplay between national public policy, international public policy and European public policy see, Kramberger Škerl J., European Public Policy (With an Emphasis on Exequatur Proceedings), Journal of Private International Law vol. 7, 2011, pp. 466-477; Kramberger Škerl J., Evropeizacija javnega reda v mednarodnem zasebnem pravu, Pravni letopis, Inštitut za primerjalno pravo pri Pravni fakulteti v Ljubljani, Ljubljani, 2009, pp. 354-358

53 Articles 15 to 20 of the PILA 2020 
regarding legal persons. ${ }^{54}$ The connecting factors regarding legal capacity and capacity to contract for natural persons have remained the same (lex nationalis). The exemptions from the main connecting factors are different. The exemption present in Article 15(2) of the PILA 2007 is changed with new rule modeled according to Article 13 of the Rome I Regulation providing for solution in cases when the contract has been concluded between persons who are in the same country. Another difference is present in Article 16(3) of the PILA 2020 from its predecessor, providing for another exemption for rights in rem on immovable property found in another country. New rule was introduced regarding natural person acting in the course of his business. ${ }^{55}$

The rules regarding guardianship and provisional protective measures ${ }^{56}$ and the rules relating declaration of death of a missing person ${ }^{57}$ have remained the same as the ones in the PILA 2007. ${ }^{58}$ General novelty in the PILA 2020 is the introduction of a new rule regarding the determination of the applicable law for personal name..$^{59}$

Regarding legal persons, the solutions adopted in the PILA 2020 are positioned around the place of registry of the legal person as a connecting factor, ${ }^{60}$ or the seat of legal person determined by its acts. ${ }^{61}$ For the organizations that are lacking legal personality, the connecting factors are the place of registry or the place of establishment of these entities. ${ }^{62}$

\section{Family law relations}

The private international family law relations cover large part of the provisions regarding the determination of the applicable law. These rules are given in Articles 24 to 50 of the PILA 2020 and cover different family law aspects: matrimonial relations and divorce, matrimonial property, relations between parents and children, maintenance and adoption.

\footnotetext{
54 Articles 21 to 23 of the PILA 2020

55 Article 17 of the PILA 2020

56 Article 18 of the PILA 2020

57 Article 19 of the PILA 2020

58 Articles 17 and 18 of the PILA 2007

59 For more on this subject see, Župan M. Nominiranje mjerodavnog prava za osobno ime - Novina Hrvatskog zakona za mecunarodnom privatnom pravu, , Collection of papers from the IX Private International Law Conference, Skopje 2011, pp. 179-193

60 Article 21(1) of the PILA 2020

61 Article 21(2) of the PILA 2020

62 Article 22 of the PILA 2020
} 
The provisions regarding the determination of the applicable law for matrimonial relations have remained almost the same as the ones in PILA 2007. Article 24 of the PILA 2020 contains the same connecting factor as the one in Article 38 of the PILA 2007 regarding conditions for conclusion of marriage that is lex nationalis for each of the spouses. What is different is the abandoning of the in concreto determination of public policy regarding these relations which was present in PILA 2007 and its predecessor. In the new PILA 2020 these aspects are covered by the general rule regarding public policy (Article 12 of the PILA 2020). The other matrimonial relations provisions have remained the same as the ones in the PILA $2007 . .^{63}$

One of the most fundamental novelties in the PILA 2020 are the new set of rules regarding divorce, modeled according to the Rome III Regulation. ${ }^{64}$ Article 27 of the PILA 2020 is modeled according to Article 8 of the Rome III Regulation ${ }^{65}$ and transposes its connecting factors (habitual residence of the spouses, last habitual residence of the spouses, nationality of the spouses and the law of the court sized) ${ }^{66}$ This is significantly different from the provisions provided in the PILA 2007 which relied on the nationality and the domicile of the spouses as a connecting factors. ${ }^{67}$ Moreover, one of the most significant novelty in the PILA 2020 is the introduction of the possibility to choose the applicable law regarding divorce. Articles 28 to 30 mimic the rules of Rome III Regulation regarding choice of law ${ }^{68}$ and provide for the first time in the Macedonian PIL possibility of the parties to choose the applicable law regarding divorce.

The matrimonial property regime in the PILA 2020 has been drafted according to the Regulation $2016 / 1103$ referring to matrimonial property regimes. ${ }^{69}$ With that the PILA 2020 allows the spouses or future spouses to choose the applicable law. ${ }^{70}$ In absence of such choice the following connecting factors are applied: the spouses' first common habitual residence after the conclusion of the marriage; the

\footnotetext{
63 Article 25 and 26 of the PILA 2020 (form of marriage and invalidity of marriage)

64 Council Regulation (EU) No 1259/2010 of 20 December 2010 implementing enhanced cooperation in the area of the law applicable to divorce and legal separation, OJEU L 343/10

65 Applicable law in the absence of choice of the parties

66 On the importance of Article 8 see, Boele Woelki K., For better or for worse: The Europeanisation of International Divorce Law, pp. 32-34

67 Article 41 of the PILA 2007

68 Boele Woelki K., For better or for worse: The Europeanisation of International Divorce Law, pp. 29-32; Kruger T., 'Rome III and Parties' Choice', Familie \& Recht, 2014, pp. 2-4

69 Council Regulation (EU) 2016/1103 of 24 June 2016 implementing enhanced cooperation in the area of jurisdiction, applicable law and the recognition and enforcement of decisions in matters of matrimonial property regimes, OJEU L183/1

$70 \quad$ Articles 32 and 33 of the PILA 2020
} 
spouses' common nationality at the time of the conclusion of the marriage; or if they don't have common nationality then the closest connection at the time of the conclusion of the marriage, taking into account all the circumstances especially the place where the marriage was concluded. ${ }^{71}$ These rules also apply to extramarital cohabitation. ${ }^{72}$

Article 38 of the PILA 2020 refers to the recognition, establishment and contesting of paternity or maternity. This rule is slightly changed from its predecessor Article 47 of the PILA 2007, still providing for the nationality of the child as a main connecting factor, but allowing for application of other law if it is more favorable towards the child (habitual residence of the child or the law which in the time of birth of the child was applicable for the relations between the spouses). The parent-child relations have been evidently changed introducing the common habitual residence or alternatively the habitual residence of the child as connecting factors. ${ }^{73}$

The maintenance relations have been also one of the main aspects which have underwent drastic change, shaping the solutions according to the EU legal sources and in this case according to the 2007 Hague Protocol. ${ }^{74}$ The situations of the applicable law regarding maintenance relations is specific in this filed, because the 2007 Hague Protocol is applicable among the Member States of the EU. ${ }^{75}$ To provide for "Europeanisation ${ }^{76}$ of this legal aspect which is one of the main principles of the PILA 2020, Articles 40 to 49 of the PILA 2020 provide for compatible solutions as those present in the 2007 Hague Protocol. ${ }^{77}$

$71 \quad$ Article 34 of the PILA 2020

72 Article 37 of PILA 2020

73 Article 39 of the PILA 2020

74 Hague Protocol of 23 November 2007 on the Law Applicable to Maintenance Obligations. More on the position of the maintenance obligations regime established by the Hague Conference see, Walker, S., Maintenance and Child Support in Private International Law, Oxford and Portland, Oregon, 2015, pp. 18-24

75 Župan, M., Innovations of the 2007 Hague Maintenance Protocol, in: Beaumont, P., et al. (ed.), The Recovery of Maintenance in the EU and Worldwide, Oxford and Portland, Oregon, 2014, p. 314

76 For more on the new tendencies in private international law in family matters see, Boele-Woelki, K., The principles of European family law: its aims and prospects, Utrecht Law Review, vol. 1, issue 2, 2005, pp. 160-168; Župan, M., Europska pravosudna suradnja u prekograničnim obiteljskim predmetima (European judicial cooperation in cross border family matters), Pravni aspekti prekogranične suradnje i EU integracija: Mađarska - Hrvatska, Pravni fakultet Sveučilišta Pečuh i Pravni fakultet u Osijeku, 2011, pp. 591-618

77 Rumenov I., Contemporary challenges of the cross border maintenance obligations system in the Republic of Macedonia, in: Duić, D.; Petrašević, T. (eds.), EU and Comparative Law Issues and Challenges Series - Issue 2, Osijek, 2018, pp. 275-288. 
What is very important in the PILA 2020 is the introduction of the rule regarding interpretation of fully transposed EU Regulations in the national law. To avoid discrepancies between the understanding of the 'national' legal provisions and the provisions present in the Maintenance Regulation, the legislator provided that the interpretation of the 'national' PILA 2020 provisions must be interpreted and applied in accordance with the Maintenance Regulation, meaning that national Courts should bear in mind the application of the Maintenance Regulation in the EU and especially the interpretation of its provisions by the Court of Justice of the European Union, although Republic of North Macedonia is still a candidate country to the European Union. This provides for full compliance of the application of the EU Regulations and the national private international law.

Lastly, the rules for the determination of the applicable law regarding adoption, have been structurally and substantially changed. First change in Article 50 of the PILA 2020 is the structure of the rule, now containing all of the aspects regarding the determination of the applicable law for adoption: conditions, termination and legal effect. Secondly, the main connecting factor for all of the aspects regarding the determination of the applicable law in the PILA 2020 is the nationality of the adoptive parent. ${ }^{78}$ If the spouses are together adopting a child the connecting factor is their common nationality or if they don't have common nationality then is their common habitual residence. ${ }^{79}$ The form of the adoption is governed by the law of the place where the adoption is created. ${ }^{80}$

\section{Succession relations}

Another significant change in the new PILA 2020 is the transposition of the rules provided in the Succession Regulation in the PILA 2020 regarding the determination of the applicable law. Chapter III of the Succession Regulation is transposed in Articles 51 to 59 of the PILA 2020 containing provisions for general rule, choice of the applicable law, scope of the applicable law, substantive validity and formal validity, validity as to form of a declaration concerning acceptance or waiver and commorientes. ${ }^{81}$

78 Article 50 of the PILA 2007 provided for the common nationality of the adoptive parent and the adopted child, or if they lacked common nationality, then it was cumulatively the laws of the states which they are nationals

79 Article 50(2) and (3) of the PILA 2020

80 Article 50(4) of the PILA 2020

81 For more on the solutions provided in the Succession Regulation see, Pfeiffer M., Legal certainty and predictability in international succession law, Journal of Private International Law, 2016, pp. 569-585 
Also for full compliance between the PILA 2020 and the Succession Regulation a rule for interpretation in accordance with the Succession Regulation is provided in the PILA 2020. ${ }^{82}$

\section{Rights in rem}

The determination of the applicable law regarding rights in rem underwent great structural change in the PILA 2020 from its predecessor. In the PILA 2007 the determination of the applicable law regarding rights in rem was contained only in one article (Article 20 of the PILA 2007) which was referring to different aspects regarding rights in rem such as: immovable property, movable property, res in transitu and means of transport. The PILA 2020 now contains 9 articles which are drafted in more details from its predecessor. ${ }^{83}$ The generally accepted connecting factors regarding rights in rem (lex rei sitae) is also the main connecting factor regarding immovable and movable property. ${ }^{84}$ One specific novelty in this section is that the legislator provided for a new rule which determines the scope of the applicable law regarding rights in rem. ${ }^{85}$

Very important novelty in the PILA 2020 is the specific provision regarding characterization of immovable and movable property, which is also conducted under the law where the property is located. ${ }^{86}$ Moreover in the PILA 2020 there are separate articles regarding conflit mobile, ${ }^{87}$ res in transitu, ${ }^{88}$ means of transport ${ }^{89}$ and validity of entry into registry. ${ }^{90}$ Also, new article was provided for determination of the applicable law regarding cultural goods. ${ }^{91}$

\section{Intellectual property rights}

In the PILA 2020, new section 5 was added in Chapter II for the determination of the applicable law regarding intellectual property rights (IP rights). This represents genuine novelty in the PILA 2020 covering different cross border issues regarding

\footnotetext{
Article 59 of the PILA 2020

Articles 60 to 68 of the PILA 2020

Articles 61 and 62 of the PILA 2020

Article 68 of the PILA 2020

Article 60 of the PILA 2020

Article 63 of the PILA 2020

Article 64 of the PILA 2020

Article 65 of the PILA 2020

Article 66 of the PILA 2020

Article 67 of the PILA 2020
} 
IP rights such as: basic rule, ${ }^{92} \mathrm{IP}$ rights arising out of labor relations, ${ }^{93}$ contracts relating to IP rights ${ }^{94}$ and infringement of IP rights. ${ }^{95}$ Regarding IP rights the main connecting factor is the country for which protection is sought, ${ }^{96}$ while for industrial property rights the country of registration. ${ }^{97}$ For the IP rights arising out of labor relations the law applicable towards the labor contract determines the titled person for the IP right if the subject of IP right arose out of labor relation. ${ }^{98}$ For the determination of the applicable law regarding IP contracts, sections 6 and 8 of the PILA 2020 applies (determination of applicable law regarding contracts and common provisions for contractual and non-contractual relations). ${ }^{99}$ The applicable law regarding infringement of IP rights is determined according to the country of protection. ${ }^{100}$

\section{Contractual obligation}

The provisions for the determination of the applicable law regarding contractual obligations continuously are modeled according to the Rome I Regulation. ${ }^{101} \mathrm{Ar}$ ticles 73 to 85 of the PILA 2020 are fully transposed from the Rome I Regulation. ${ }^{102}$

For full compliance between the PILA 2020 and the Rome I Regulation a rule for interpretation in accordance with the Rome I Regulation is provided in the PILA $2020 . .^{103}$

\footnotetext{
92 Article 69 of the PILA 2020

93 Article 70 of the PILA 2020

94 Article 71 the PILA 2020

95 Article 72 of the PILA 2020

96 Article 69 (1) of the PILA 2020

97 Article 69 (2) of the PILA 2020

98 Article 70 of the PILA 2020

99 Article 71 of the PILA 2020

100 Article 72 of the PILA 2020

101 Regulation (EC) No 593/2008 of the European Parliament and of the Council of 17 June 2008 on the law applicable to contractual obligations (Rome I), OJEU L177/6

102 For more on the Rome I Regulation see, Deskoski T.; Dokovski V., Lex Contractus for Specific Contracts under Rome I Regulation, pp. 2-12; Lando O.; Nielsen P.A., The Rome I Proposal, Journal of Private International Law, 2007, pp. 29-51; Maultzsch F., Party autonomy in European private international law: uniform principle or context-dependent instrument?, Journal of Private International Law, 2016, pp. 466-491; Le Verhagen H.; van Dongen S., Cross-Border Assignments under Rome I, Journal of Private International Law, 2010, pp. 1-21

103 Article 85 of the PILA 2020
} 


\section{Non-contractual obligations}

The provisions for the determination of the applicable law regarding contractual obligations continuously are modeled according to the Rome II Regulation. ${ }^{104}$ Articles 86 to 98 of the PILA 2020 are fully transposed from the Rome II Regulation.

For full compliance between the PILA 2020 and the Rome II Regulation a rule for interpretation in accordance with the Rome II Regulation is provided in the PILA 2020. ${ }^{105}$

Another novelty regarding contractual and non-contractual obligations is the new section 8 of the PILA 2020 which contains common provisions for these relations.

8. Formal validity of legal transactions and legal acts, contractual agency and statute of limitations

The last section of Chapter II of the PILA 2020 refers to several specific relations such as formal validity of legal transactions and legal acts ${ }^{106}$, contractual agency ${ }^{107}$ and statute of limitations. ${ }^{108}$ In comparison with the PILA 2007, out of the rules provided in the PILA 2020 only the rule regarding contractual agency is a novelty, while the other two rules have remained unchanged.

\subsubsection{New solutions regarding the international jurisdiction and procedure}

The three basic principles upon which the PILA 2020 is based, are also present in Part III of this act that refers to international jurisdiction and procedure. Part III is divided in two chapters, Chapter I refereeing to international jurisdiction and Chapter II referring to international procedure.

104 For more on the application of the Rome II Regulation in the EU see, Kramer, op cit. note 14, pp. 414-424; Ahern B.; Binchy W. (eds.), The Rome II Regulation on the Law Applicable to Non-Contractual Obligation - A New International Litigation Regime, pp. 1-473; Pineau E.R., Conflict of Laws Comes to the Rescue of Competition Law: the New Rome Ii Regulation, Journal of Private International Law, 2009, pp. 311-336; Papettas, J. Direct Actions against Insurers of Intra-Community Cross-Border Traffic Accidents: Rome II and the Motor Insurance Directives, Journal of Private International Law, 2012, pp. 297-321; Nagy, C. I. The Rome II Regulation and Traffic Accidents: Uniform Conflict Rules with some Room for Forum Shopping - How so? Journal of Private International Law, 2010, pp. 93-108

105 Article 103 of the PILA 2020 provides for interpretation of the rules regarding the determination of the applicable law for non-contractual relations but with exemption to Articles 93, 94 and 95 of the PILA 2020

106 Article 107 of the PILA 2020

107 Article 108 of the PILA 2020

108 Article 109 of the PILA 2020 


\subsubsection{International Jurisdiction}

\section{General provisions}

The simplicity and consistency of the PILA 2020 is evident in the first section of Chapter I, giving the general provisions for international jurisdiction. This section, among other, contains provisions for general jurisdiction in contentious procedure, ${ }^{109}$ general jurisdiction for non-contentious procedure, ${ }^{110}$ international jurisdiction for counterclaims, ${ }^{111}$ international jurisdiction for provisional measures ${ }^{112}$ perpetuation fori ${ }^{113}$ forum necessitates, ${ }^{114}$ general rule for exclusive jurisdiction, ${ }^{115}$ lis pendens rule ${ }^{116}$ and other rules. ${ }^{117}$

The main novelty regarding the provisions for general jurisdiction both in contentious and in non-contentious procedure is the introduction of habitual residence of the defendant as a jurisdictional criterion. ${ }^{118}$ The domicile of the defendant is still present as a jurisdictional criterion but now it is given alternatively with the habitual residence of the defendant. So the general jurisdiction of Courts of N. Macedonia are determined if the defendant (which is natural person) has domicile or habitual residence in N. Macedonia. Regarding the general jurisdictional criterion for legal persons in both procedures there is separate provision which is determining the jurisdiction of Courts of $\mathrm{N}$. Macedonia according to the seat of the legal person. ${ }^{119}$ Another novelty is the provision in the PILA 2020 that excludes the succession from general jurisdiction. ${ }^{120}$

Important novelty in this section in the PILA 2020 is the introduction of specific rules for determining jurisdiction regarding provisional measures, rule for forum necessitates and general rule for exclusive jurisdiction. Such rules were not present in the PILA 2007.

\footnotetext{
109 Article 110 of the PILA 2020

110 Article 114 of the PILA 2020

111 Article 113 of the PILA 2020

112 Article 115 of the PILA 2020

113 Article 116 of the PILA 2020

114 Article 117 of the PILA 2020

115 Article 118 of the PILA 2020

116 Article 119 of the PILA 2020

117 Unity of interest (Article 111 of the PILA 2020); jurisdiction for related claims (Article 112 of the PILA 2020); exclusive jurisdiction for approving and conducting enforcement (Article 120 of the PILA 2020) and International jurisdiction for claims against citizens of Republic of North Macedonia which are in service abroad (Article 121 of the PILA 2020).

118 Article 110 (1) of the PILA 2020 and Article 114 (1) of the PILA 2020

119 Article 110 (1) of the PILA 2020 and Article 114 (1) of the PILA 2020

120 Article 110 (2) of the PILA 2020 and Article 114 (3) of the PILA 2020
} 
There is certain amendment to the rules regarding lis pendens. In the PILA 2020 it is required an additional condition for application of this rule: reasonably to expect that the foreign Court would render a decision that could be recognized in Republic of North Macedonia. ${ }^{121}$ The other criteria are as same as those in the PILA 2007(same subject matter, same parties, the procedure was initiated firstly before the foreign court and the dispute does not fall under exclusive jurisdiction of Courts of Republic of N. Macedonia). ${ }^{122}$

The provisions regarding assessment of the jurisdiction of the Court of Republic of N. Macedonia underwent certain change. Firstly the new provisions in Article 116 of the PILA 2020 specifically state that the international jurisdiction is determined ex officio. Secondly, the jurisdiction is determined according to the facts and the circumstances that exist when the procedure is initiated. ${ }^{123}$ This is different from the provision in the PILA 2007 where the time when the facts were determined was the time when the procedure was individualized (made in concreto) that is the time when the suit was served to the defendant. ${ }^{124}$ Article 116 (2) of the PILA goes even further from Article 94 of the PILA 2007 and unambiguously provides that even where the circumstances and the fact change, this would not influence the determined jurisdiction of the Courts of N. Macedonia.

\section{Choice of Court Agreement}

Section 2 of the PILA 2020 now is dedicated to the prorogation of the jurisdiction. This section has been modified and constructed according to the Brussels Ibis Regulation. ${ }^{125}$ Articles 122 to 125 mirror the provisions in Section 7 of Brussels Ibis Regulation and the wording of these provisions tries to follow the wording of the provisions in the Brussels Ibis Regulation. In comparison with the PILA 2007, one of the most significant novelties is provided in Article 122 of the PILA

121 Article 119 of the PILA 2020

122 Article 93 of the PILA 2007

123 Article 116 of the PILA 2020

124 Article 94 of the PILA 2007

125 Regulation (EU) No 1215/2012 of the European Parliament and of the Council of 12 December 2012 on jurisdiction and the recognition and enforcement of judgments in civil and commercial matters, OJEU L351/1. For more on the jurisdictional agreements in the Brussels Ibis Regulation see, Forner-Delaygua, Q., Changes to jurisdiction based on exclusive jurisdiction agreements under the Brussels I Regulation Recast, Journal of Private International Law, 2015, pp. 379-405; Ratković, T.; Zgrabljić Rotar, D., Choice-of-Court Agreements under the Brussels I Regulation (Recast), Journal of Private International Law, 2013, pp. 245-268; Kistler, A. R. E. Effect of exclusive choice-of-court agreements in favour of third states within the Brussels I Regulation Recast, Journal of Private International Law, 2018, pp. 66-95; Ballesteros, M. H., The Regime of Party Autonomy in the Brussels I Recast: the Solutions Adopted for Agreements on Jurisdiction, Journal of Private International Law, 2014, pp. 291-308; Weller, M., Choice of court agreements under Brussels Ia and under the Hague convention: coherences and clashes, Journal of Private International Law, 2017, pp. 91-129 
2020 which refers to prorogation of jurisdiction of the Courts of Republic of N. Macedonia. According to this provision exclusive jurisdiction status is attributed to the prorogation of the jurisdiction of Courts of N. Macedonia. ${ }^{126}$ With such position, the prorogation of jurisdiction of Courts of N. Macedonia are afforded all of the modalities for protection of the exclusive jurisdiction in the PILA 2020 such as the lis pendes rule ${ }^{127}$ and non-recognition of foreign decisions that are in breach of prorogation of Courts of Republic of N. Macedonia. ${ }^{128}$ The effect of the exclusive jurisdictional aspect of choice of Court agreements is not absolute, since it is left to the parties to opt for such effect. ${ }^{129}$

Another important difference from the PILA 2007 is that to choose the Courts of Republic of N. Macedonia, it is not required in the PILA 2020 for one of the parties to be Macedonian citizen or if it is legal person to have its situs in N. Macedonia. ${ }^{130}$ Also to choose foreign Court, in the PILA 2020 it is not required for one of the parties to be a foreign citizen or if it is a legal person to have its situs in N. Macedonia. ${ }^{131}$

For the formal validity of the choice of Court agreements, the conditions mimic the provisions of Article 25 (a) to (c) of the Brussels Ibis Regulation. Also there is possibility of tacit choice of Court in the situations where the defendant entered in appearance either by submitting response of the lawsuit, entered in appearance for the main issue without contesting the jurisdiction or filed a counterclaim. ${ }^{132}$

\section{Specific provisions}

The specific provisions regarding jurisdiction follow the systematization of the provisions regarding the determination of the applicable law. Section 3 of Chapter I in Part III is divided in subsections containing specific jurisdiction provisions for status of persons, ${ }^{133}$ family relations, ${ }^{134}$ succession, ${ }^{135}$ rights in rem, ${ }^{136}$ intellectual property rights, ${ }^{137}$ contractual and non-contractual relations. ${ }^{138}$

\footnotetext{
126 Article 122 (2) of the PILA 2020

127 Article 119 of the PILA 2020

128 Article 160 of the PILA 2020

129 Article 122(2) of the PILA 2020

130 Article 56 (3) of the PILA 2020

131 Article 56(1) of the PILA 2020

132 Article 125 (1) of the PILA 2020

133 Articles 126 to 130 of the PILA 2020

134 Articles 131 to 136 of the PILA 2020

135 Articles 137 to 140 of the PILA 2020

136 Articles 141 to 143 of the PILA 2020

137 Article 144 of the PILA 2020

138 Articles 145 to 150 of the PILA 2020
} 
The legislator in the PILA 2020 has done important changes with the specific jurisdiction. Firstly, the situations where the exclusive jurisdiction was attributed to the Courts of N. Macedonia has been reduced. In the PILA 2007 there were 13 situations of exclusive jurisdiction of Courts of N. Macedonia. ${ }^{139}$ In the PILA 2020 only 7 situations are attributed with exclusive jurisdiction of Courts of N. Macedonia. ${ }^{140}$ Secondly, in family matters, ${ }^{141}$ maintenance ${ }^{142}$ and succession, ${ }^{143}$ habitual residence was introduced as jurisdictional criterion. Lastly, limited prorogation of jurisdiction was introduced regarding succession. ${ }^{144}$

\subsubsection{International procedure}

The provisions regarding international procedure have been structurally altered and in the recomposition of Part III of the PILA 2020 many of the rules which were present in PILA 2007, have been transferred to the new Section 1 in the PILA 2020 regarding general provisions for international jurisdiction. ${ }^{145}$ There are four aspects in this section, first, the provision regarding applicable law for the procedure with cross border aspect; ${ }^{146}$ second, capacity to be a party in a lawsuit and capacity to conduct legal proceedings; ${ }^{147}$ third, cautio iudicatum solvi, ${ }^{148}$ and lastly exemption from payment of costs of litigation. ${ }^{149}$

Regarding the applicable law for the procedure conducted in front of Courts in N. Macedonia provided in Article 151 of the PILA 2020, the applicable law is the law of Republic of N. Macedonia. The provisions in the PILA 2020 regarding the capacities to be a party in a lawsuit and capacity to conduct legal proceedings have remained the same as the ones provided in the PILA 2007.150 The provisions regarding cautio iudicatum solvi in the PILA 2020 are generally unchanged from the PILA 2007 with some amendments: foreign legal persons that are not enlisted in the registry have to provide security for the payment of the costs of

\footnotetext{
139 Articles 65, 66, 67, 68, 63, 84, 85, 86, 73 (2), 76 (2), 78 (2), 83 (2), 87, 88 and 91 of the PILA 2007

140 Articles 122(2), 129, 130, 136 (2), 141, 144 and 147

141 Article 131 of the PILA 2020

142 Article 135 of the PILA 2020

143 Article 137 of the PILA 2020

144 Article 140 of the PILA 2020

145 The provisions regarding foreign lis pendens (Article 93 of the PILA 2007) and perpetuation fori (Article 94 of the PILA 2007) are in the PILA 2020 transferred to the general part of the international jurisdiction

146 Article 151 of the PILA 2020

147 Article 152 of the PILA 2020

148 Articles 153 to 155 of the PILA 2020

149 Article 156 of the PILA 2020

150 In comparison see Article 92 of the PILA 2007 and Article 152 of the PILA 2020
} 
litigation. ${ }^{151}$ The rules regarding exemptions for payment of costs of litigation have been changed, providing that these exemptions are not conditioned anymore with reciprocity but these rules are available for foreign citizens under conditions applicable towards the citizens of Republic of N. Macedonia. ${ }^{152}$

\subsubsection{New solutions regarding recognition and enforcement of foreign decisions}

The three basic principles upon which the PILA 2020 is based, also prevail in Part IV of this act that refers to recognition and enforcement of foreign decisions. Part IV is divided in three chapters, Chapter I definitions; Chapter II conditions for recognition and enforcement and Chapter III procedure for recognition and enforcement. In comparison to the PILA 2007 this part follows the systematic division of its predecessor however with some novelties.

\subsubsection{Definitions}

The provisions in this section remain the same as the provisions in the PILA 2007. The definitions regarding what should be considered as 'foreign judicial decision' in the PILA 2020 remains the same as the ones provided in the PILA 2007. ${ }^{153}$ Also the provision regarding the definition of 'recognition' remains the same without any change. ${ }^{154}$

\subsubsection{Conditions for recognition and enforcement}

The provisions of the PILA 2020 regarding the conditions for recognition and enforcement of foreign judicial decision in comparison to the provisions in PILA 2007 underwent structural and substantial modification. Firstly, this Chapter II of Part IV is divided in two sections: Section 1 which provides for the conditions for recognition and enforcement of foreign decisions that are considered ex officio by the Court; and Section 2 that provides for the conditions that are considered upon objection by the parties. Secondly, in line with the tendency of the PILA 2020 the conditions have been amended and reduced.

1. Conditions that are considered ex officio

One of the greatest novelties regarding the recognition and enforcement of foreign judicial decisions in N. Macedonia is that the Court of recognition inspects most

\footnotetext{
151 Article 153(1) of the PILA 2020

152 Article 156 of the PILA

153 Article 99 of the PILA 2007 and Article 157 of the PILA 2020

154 Articles 100 of the PILA 2007 and Article 158 of the PILA 2020
} 
of the conditions ex officio and thus provides for swift recognition based on objective circumstances. Most of the conditions for recognition in the PILA 2020 were present in its predecessor. The certificate of finality and enforceability provided in Article 159 of the PILA 2020 is combination of Article 101 and 102 of the PILA 2007. The wording of these provisions has remained unchanged. Regarding the exclusive jurisdiction of courts of N. Macedonia, the provision from its counterpart in the PILA $2007^{155}$ is simplified, providing that foreign judicial decision would not be recognized in N. Macedonia if exclusive jurisdiction over the matter lies with the court or some other authority in Republic of N. Macedonia, unless the provisions of the PILA 2020 allow the parties to choose otherwise. ${ }^{156}$

One of the novelties regarding the condition for recognition and enforcement is that as a prevention from exorbitant jurisdiction, the legislator opted to incorporate 'mirror principle' meaning that foreign judicial decision would not be recognized in Republic of N. Macedonia, if the jurisdiction was determined according to circumstances which are not provided for determination of the jurisdictions for complementary cross border issues in Republic of N. Macedonia. ${ }^{157}$

The provisions in the PILA 2020 regarding parallel proceedings, solve this problem with the rules regarding lis pendens ${ }^{158}$ and the provisions provided in Article 162 which determine that foreign judicial decision shall not be recognized if the court or another authority in N. Macedonia rendered a final decision on the same subject matter or if another foreign judicial decision on the same subject matter and between the same parties was recognized in Republic of N. Macedonia. ${ }^{159}$ This provision sustained a slight but very important change regarding the identity of the parties, because Article 106 of the PILA 2007, provided for the foreign judicial decision which was previously recognized, that only the subject matter of both decisions should correspond, while the provision in Article 164 of the PILA 2020 ask for both of the judicial decisions to be “...on the same subject matter and between the same parties...". Paragraph 2 of Article 164 of the PILA 2020 remains the same as Article 106 (2) of the PILA 2007.

Another significant novelty in the PILA 2020 that goes in line with the new tendencies in private international law, ${ }^{160}$ is the higher threshold that is required in

155 Article 104 of the PILA 2007
156 Article 160 of the PILA 2020
157 Article 161 of the PILA 2020
158 Article 119 of the PILA 2020
$159 \quad$ Article 162 of the PILA 2020
$160 \quad$ Kramberger Škerl J., European Public Policy (With an Emphasis on Exequatur Proceedings), pp. 466-477;
Kramberger Škerl J., Evropeizacija javnega reda v mednarodnem zasebnem pravu, pp. 349-370; Hess B.; 
order to apply the 'public policy' exemption. Article 107 of the PILA 2007 provided that foreign judicial decision would not be recognized in Republic of N. Macedonia on the grounds of public policy. For this clause to take effect the provision of 'public policy' only required that if the effects of recognition thereof were contrary to public policy of $\mathrm{N}$. Macedonia then this exemption could be applied. Article 163 of the PILA 2020 elevates the threshold higher to the standard "evidently contrary to public policy". Such wording is not only semantically significant, but provides for much more restrictive approach to the use of 'public policy' exemption. ${ }^{161}$

\section{Conditions that are considered upon objection by the parties}

The possibility to refuse to recognize a foreign decision upon objection by the parties has been limited to the minimum in the PILA 2020 only in the cases against severe violations by the judicial authorities of the Country of origin. ${ }^{162}$ The evolutionary path of the provision regarding 'violation of the right of defense' as a condition for recognition and enforcement of foreign judicial decision in the Macedonian private international law can be seen in this rule. Article 104 of the PILA 2007 went further from the provision on 'right of defense' given in Article 88 of the PILA 1982. Namely, Article 88 (1) contained general condition that: "The court of the Republic of Macedonia shall refuse the recognition of a foreign judicial decision if upon objection the person against whom the decision was rendered it has been established that due to irregularities in the proceedings he had no opportunity to participate therein". From this position Article 88(2) of PILA 1982 provided for in concreto scenarios regarding infringement of the right of service of documents in the procedure. ${ }^{163}$ The PILA 2007 modified this rule in two aspects: firstly, the provisions didn't went from general to specific, rather as two aspects of the infringement of the right of defense; and secondly, regarding the service of documents specific reference to the law according to which the service needs to be conducted was provided (the law of the country of origin). The PILA 2020 modifies this rule in two aspects: firstly, it left out the specific reference to

Pfeifer T., Study on the Interpretation of the Public Policy Exception as referred to in EU Instruments of Private International and Procedural Law, pp. 1-181; Siehr K, General problems of private international law in modern codifications - de lege lata and - de lege europea ferenda, Yearbook of Private International Law, 2005, p. 54

161 Hess B.; Pfeifer T., Study on the Interpretation of the Public Policy Exception, p. 13

162 Article 164 of the PILA 2020

163 In particular, a person against whom a foreign judicial decision was rendered shall be considered as having no opportunity to participate in the proceedings if the summons, the document or the ruling instituting the proceedings were not served upon him in person or if service in person was not even tried, except when the person pleaded to the merits of the plaintiffs claim in the first instance procedure. Article 88(2) of the PILA 1982 
the law according to which the service needs to be conducted was provided; and secondly it provides for third in concreto scenario, that the party was not given sufficient time to arrange its defense from the moment of service of the document instituting the proceeding until moment when the hearing was scheduled. ${ }^{164}$

\section{Procedure for recognition of foreign judicial decisions}

The core of the procedure for recognition and enforcement of foreign judgments has generally remained the same as the procedure in the PILA 200. The novelties in the procedure for recognition and enforcement are relating to two aspects: firstly, the time limits have been prolonged; ${ }^{165}$ and secondly the adversarial hearing in the second stage of the procedure for recognition is obligatory. ${ }^{166}$

\section{CONCLUSION}

It can be said that the PILA 2020 represents a significant step forward for the Macedonian private international law, bridging the new tendencies in private international law and Europeanizing the core understanding of its institutes. The systematization that has be introduced in this new PIL code, provides for much easier implementation from practitioners soliciting in N. Macedonia. It will represent a challenge for the judiciary to consume such large structural change of private international law, however to achieve the main goal of the law, that is to bring closer the EU private international law rules, this mustn't represent an obstacle. When the judiciary adopts to these provisions in the PILA 2020, then the immanent move to the EU private international law regulations would not represent tremendous problem. With that, the PILA 2020 solves two problems with one act, it evolutionary modernizes the national private international law and provides for easier adaptation to the EU regulations.

Very important provisions in the PILA 2020 are the rules for interpretation regarding the provisions which represent fully transposed EU regulations. These rules would allow the judiciary to comply its national law to the standards and interpretations of the EU institutes and with that to go in line with the interpretation provided in EU, although $\mathrm{N}$. Macedonia is still just a candidate country to the EU. Without these provisions, there would still be a possibility of distortion of the understanding of EU legal institutes and with that the goal of harmonization of the internal law with the EU law would not be achieved. The PILA 2020

\footnotetext{
164 Article 164 of the PILA 2020

165 Article 168 and 170 of the PILA 2020

166 Article 169 of the PILA 2020
} 
will also represent a model for a modern national private international law act that other countries can follow.

\section{REFERENCES}

\section{BOOKS AND ARTICLES}

1. Ahern B.; Binchy W. (eds.), The Rome II Regulation on the Law Applicable to Non-Contractual Obligation - A New International Litigation Regime, Martinus Nijhoff Publishers, Leiden Boston, 2009

2. Ballesteros, M. H., The Regime of Party Autonomy in the Brussels I Recast: the Solutions Adopted for Agreements on Jurisdiction, Journal of Private International Law, 2014, pp. 291-308

3. Behr V., Rome I Regulation a-Mostly-Unified Private International Law of Contractual Relationships within-Most - of the European Union, Journal of Law and Commerce, vol. 29, no. 2, 2019, pp. 233-272

4. Boele Woelki K., For better or for worse: The Europeanisation of International Divorce Law, Yearbook of Private International Law, vol. 12, 2010, pp. 1-26

5. Boele-Woelki, K., The principles of European family law: its aims and prospects, Utrecht Law Review, vol. 1, issue 2, 2005, pp. 160-168

6. Crawford E.B.; Carruthers J.M, Connection and Coherence Between and Amoung European Instruments in the Private International Law of Obligations, International and Comparative Law Quarterly, vol. 63, 2014, pp. 1-29

7. De Lange R., The European Public Order, Constitutional Principles and Fundamental Rights, Erasmus Law review, 2007, pp. 3-24

8. Deskoski T.; Dokovski V., Lex Contractus for Specific Contracts under Rome I Regulation, Iustinianus Primus Law Review, vol. 10, 2019, pp. 1-12

9. Deskoski T., The new Macedonian Private International Law Act of 2007, Yearbook of Private International Law, vol. X, 2008, pp. 441-459

10. Dika M.; Knežević G.; Stojanović S., Komentar zakona o mectunarodnom privatnom i procesnom pravu, Nomos, 1991

11. Forner-Delaygua, Q., Changes to jurisdiction based on exclusive jurisdiction agreements under the Brussels I Regulation Recast, Journal of Private International Law, 2015, pp. 379-405

12. Hellner M., Third Country Overriding Mandatory Rules in the Rome I Regulation: Old Wine in New Bottles?, Journal of Private International Law, 2009, pp. 447-470

13. Hess, B.; Law, S.; Ortolani P. (eds.), An evaluation study of national procedural laws and practices in terms of their impact on the free circulation of judgments and on the equivalence and effectiveness of the procedural protection of consumers under EU consumer law, JUST/2014/ RCON/PR/CIVI/0082, 2017, pp. 1-368

14. Hoško T., Public Policy as an Exception to Free Movement within the Internal Market and the European Judicial Area: A Comparison, Croatian Yearbook of European Law and Policy, vol. 10, 2014, pp. 189-213

15. Kessedijan C., Public Order in European Law, Erasmus Law Review, vol. 1, 2007, pp. 25-36; 
16. Kistler, A. R. E., Effect of exclusive choice-of-court agreements in favour of third states within the Brussels I Regulation Recast, Journal of Private International Law, 2018, pp. 66-95

17. Kramberger Škerl J., European Public Policy (With an Emphasis on Exequatur Proceedings), Journal of Private International Law vol. 7, 2011, pp. 466-477

18. Kramberger Škerl J., Evropeizacija javnega reda v mednarodnem zasebnem pravu, Pravni Letopis, Ljubljana, 2008, pp. 355-375

19. Kramer X. et al., A European framework for private international law: current gaps and future perspectives, Study, European Parliament 2012;

20. Kramer X., 'European Private International Law: The Way Forward. Indepth analysis' in Workshop on Upcoming Issues of EU Law, European Parliament, Brussels, 2014

21. Kramer X., Current gaps and future perspectives in European private international law: towards a code on private international law? Briefing note, European Parliament, 2012

22. Kramer X., The Rome II Regulation on the Law Applicable to Non-Contractual Obligations: The European private international law tradition continued, Nederlands Internationaal Privaatrecht, NIPR, 2008

23. Kruger T., 'Rome III and Parties' Choice', Familie \& Recht, 2014

24. Lando O.; Nielsen P.A., The Rome I Proposal, Journal of Private International Law, 2007, pp. 29-51

25. Le Verhagen H.; van Dongen S., Cross-Border Assignments under Rome I, Journal of Private International Law, vol. 6, 2010, pp. 1-21

26. Maultzsch F., Party autonomy in European private international law: uniform principle or context-dependent instrument?, Journal of Private International Law, 2016, pp. 466-491

27. Nagy, C. I., The Rome II Regulation and Traffic Accidents: Uniform Conflict Rules with some Room for Forum Shopping - How so?, Journal of Private International Law, 2010, pp. 93-108

28. Papettas, J. Direct Actions against Insurers of Intra-Community Cross-Border Traffic Accidents: Rome II and the Motor Insurance Directives, Journal of Private International Law, 2012, pp. 297-321

29. Pauknerová, M. Mandatory rules and public policy in international contract law, ERA Forum 11,2010

30. Pfeiffer M., Legal certainty and predictability in international succession law, Journal of Private International Law, 2016, pp. 569-585

31. Pineau E.R., Conflict of Laws Comes to the Rescue of Competition Law: the New Rome Ii Regulation, Journal of Private International Law, 2009, pp. 311-336

32. Ratković, T.; Zgrabljić Rotar, D., Choice-of-Court Agreements under the Brussels I Regulation (Recast), Journal of Private International Law, 2013, pp. 245-268

33. Rumenov I., Contemporary challenges of the cross border maintenance obligations system in the Republic of Macedonia, in: Duić, D.; Petrašević, T. (eds.), EU and Comparative Law Issues and Challenges Series - issue 2, Osijek, 2018, pp. 275-288

34. Rumenov I., Determination of the Child's Habitual Residence According to the Brussels II bis Regulation, Pravni Letopis, Inštitut za primerjalno pravo pri Pravni fakulteti v Ljubljani, Ljubljana Slovenia, 2013, pp. 57-81 
35. Rumenov I., The legal paradox of child's habitual residence: How to uniformly understand a factual concept?, Iustinianus Primus Law Review, vol. V, no. 8, 2014, pp. 1-15

36. Siehr K, General problems of private international law in modern codifications - de lege lata and-de lege europea ferenda, Yearbook of Private International Law, 2005, pp. 17-63

37. Varadi T. et al., Mecunaodno privatno pravo, deseto izdanje, JP “Službeni Glasnik', Beograd, 2008

38. Von Hein; Rühl G., 'Towards a European code on private international law? Study', in Crossborder activities in the EU: Making life easier for citizens, Workshop for the JURI Committee, European Parliament, 2015

39. Walker, S., Maintenance and Child Support in Private International Law, Oxford and Portland, Oregon, 2015

40. Weller, M., Choice of court agreements under Brussels Ia and under the Hague convention: coherences and clashes, Journal of Private International Law, 2017, pp. 91-129;

41. Živković M.; Stanivuković M, Međunarodno privatno pravo (opšti deo), Beograd, Službeni glasnik, 2006

42. Župan M. Nominiranje mjerodavnog prava za osobno ime - Novina Hrvatskog zakona za medunarodnom privatnom pravu, Collection of papers from the IX Private International Law Conference, Skopje, 2011, p.179-193

43. Župan, M., Europska pravosudna suradnja u prekograničnim obiteljskim predmetima (European judicial cooperation in cross border family matters), Pravni aspekti prekogranične suradnje i EU integracija: Mađarska - Hrvatska, Pravni fakultet Sveučilišta Pečuh i Pravni fakultet u Osijeku, 2011, pp. 591-618

44. Župan, M., Innovations of the 2007 Hague Maintenance Protocol, in Beaumont, P., et al. (eds.), The Recovery of Maintenance in the EU and Worldwide, Oxford and Portland, Oregon, 2014, pp. 311-328

45. Гавроска П., Дескоски Т., Меѓународно приватно право, Скопје, 2011

46. Џунов Т. Меѓународно приватно право, Скопје, 1995

\section{EU LAW AND INTERNATIONAL AGREEMENTS}

1. Council Regulation (EU) 2016/1103 of 24 June 2016 implementing enhanced cooperation in the area of jurisdiction, applicable law and the recognition and enforcement of decisions in matters of matrimonial property regimes, OJEU L183/1

2. Council Regulation (EU) No 1259/2010 of 20 December 2010 implementing enhanced cooperation in the area of the law applicable to divorce and legal separation, OJEU L 343/10

3. Hague Protocol of 23 November 2007 on the Law Applicable to Maintenance Obligations

4. Regulation (EC) No 593/2008 of the European Parliament and of the Council of 17 June 2008 on the law applicable to contractual obligations (Rome I), OJEU L177/6

5. Regulation (EC) No 864/2007 of the European Parliament and of the Council of 11 July 2007 on the law applicable to non-contractual obligations (Rome II), OJEU L 199/40 
6. Regulation (EU) No 1215/2012 of the European Parliament and of the Council of 12 December 2012 on jurisdiction and the recognition and enforcement of judgments in civil and commercial matters, OJEU L351/1

7. Regulation (EU) No 650/2012 of the European Parliament and of the Council of 4 July 2012 on jurisdiction, applicable law, recognition and enforcement of decisions and acceptance and enforcement of authentic instruments in matters of succession and on the creation of a European Certificate of Succession, OJEU, L 201/107

8. Regulation EC 593/2008 of the European Parliament and of the Council of 17 June 2008 on the law applicable to contractual obligations (Rome I), Official Journal of the European Union L 177/6

9. Stabilisation and Association Agreement between the European Communities and their Member States, of the one part, and the former Yugoslav Republic of Macedonia, of the other part, Official Gazette of Republic of Macedonia, no. 28/2001

\section{LIST OF NATIONAL REGULATIONS AND ACTS}

1. Act Concerning the Resolution of Conflicts of Laws with Provisions of Other States in Certain Matters (Закон за решавање на судирот на законите со прописите на другите држави во одредени односи), Official Gazette of the SFRY, no.43/1982

2. Law on civil procedure, Official Gazette of the FPRY, no.4/57

3. Law on Enforcement procedure, Official Gazette of the SFRY, no.20/78

4. Private International Law Act (Закон за меѓународно приватно право), Official Gazette of Republic of Macedonia, no. 87/2007 and 156/2010

5. Private International Law Act (Закон за меѓународно приватно право), Official Gazette of Republic of North Macedonia, no. 32/2020

\section{WEBSITE REFERENCES}

1. Hess B.; Pfeifer T., Study on the Interpretation of the Public Policy Exception as referred to in EU Instruments of Private International and Procedural Law, prepared for the European Parliament's Committee on Legal Affairs [https://www.europarl.europa.eu/thinktank/en/document.html?reference=IPOL-JURI_ET\%282011\%2945318], accessed 12. July 2020

2. Kramer, X., A Common Discourse in European Private International Law? A View from the Court System, in: von Hein J.; Kieninger E.M.; Rühl G., (eds.), How European Is European Private International Law, Intersentia 2018/19, [https://ssrn.com/abstract=3207771], accessed 12. July 2020

3. Van Den Eeckhout, V., The Instrumentalisation of Private International Law: Quo Vadis? Rethinking the 'Neutrality' of Private International Law in an Era of Globalisation and Europeanisation of Private International Law, August 22, 2013, [https://ssrn.com/abstract=2338375], accessed 12. July 2020 